\title{
Ridiculing the Female Characters in Israeli Hebrew Children's Literature - From a Gender-Oriented Stereotype to a Feminist Protest
}

\author{
Nitsa Dori \\ Correspondence: Dr. Nitsa Dori, Head of the Department of Early Childhood, Shaanan Academic College, Haifa, Israel.
}

Received: Apr. 7, 2020

doi:10.11114/smc.v8i1.4844
Accepted: Apr. 20, $2020 \quad$ Online Published: May 6, 2020

URL: https://doi.org/10.11114/smc.v8i1.4844

\begin{abstract}
The differences between the genders and attitudes toward the feminine and masculine domains are already recognizable during early childhood. Blatant sexism can be distinguished in a number of Israeli Hebrew children's books written several decades ago on the subject of the grotesque woman, and which have become classics still read in preschools. The women in these stories are described as bewildered, confused, and absentminded. Since these Hebrew literary texts are extremely popular among preschool teachers, this article firstly promotes awareness of the issue. Later, this article will suggest a new way of reading that will lead to deeper understanding of the messages and change gender-oriented stereotypes, common in the past, to a feminist protest of the present. Discussion and conversation with children regarding the essence of the gender-oriented viewpoint in shaping the grotesque woman, its motives, and other insights that can be reached through the figure's activity, conversation, and behaviour, can serve as a tool for the development of a person capable of critical thinking, independence, and having values.
\end{abstract}

Keywords: Gender, children's literature, stereotypes, protest, feminism

\section{Introduction}

One of a child's basic needs which he can realize through a story is that of identification. 1 The child's emotional identification with the heroes of the story, their adventures and fate, leads to subconscious absorption of the values, character traits, and views of the heroes who symbolize them with their personality and deeds. 2 Children's books are one method of transmitting culture to children and shaping their viewpoints.3

The article will discuss several representative Hebrew texts, told in Israeli preschools - two stories by Yoram Taharlev: Gveret Achat Mirehov Bezalel [The Lady From Bezalel Street]4, and Hadoda Sheli Mirehov Hanevi'im [My Aunt from Hanevi'im Street]5; three stories by Datia Ben Dor: Gveret Keresh U'Mar Maarokh [Mrs. Cutting Board and Mr. Rolling Pin]6, Haruzim Te'imimim [Tasty Rhymes]7, and Savta Minna Mibinyamina [Grandma Minna from Binyamina]8, Talma Alyagon Roz and Haya Frankel's poem: Ma'aseh B'levivot [A Story About Potato Pancakes] (1971)9 as compared to the story by Levin Kipnis: Ma'aseh B'ozenhaman [A Story About A Three-Cornered Pastry]10, and Haya Shenhav's song Gveret Im Salim [A Lady With Baskets] (1989).11.

\footnotetext{
${ }^{1}$ Michael Desheh, Hinukh Likri'ah Tovah: Al Sifrut Yeladim V'al Ba'ayot Hakri'ah Hahofshit (Tel Aviv: Am Oved, 1969).

${ }^{2}$ Ariella Krasney, 'Hatefisah Hastereotipit Shel Demut Ha'ishah Besifrut Hayeladim', Sha'anan, 10 (2005), 197-216.

${ }^{3}$ Nava Sagan and A. Katzowitz, 'Stereotipim Gavri'im U'nashi'im Besifre Limud Uvesifrut Yeladim V'no'ar' in Matsa Min Et Shivyono, ed. by Nava Sagan (Jerusalem: Israeli Ministry of Education, 1993).

${ }^{4}$ Gveret Achat Mirehov Bezalel (Ben Shemen: Modan, 1967).

${ }^{5}$ Hadoda Sheli Mirehov Hanevi'im (Tel Aviv: Am Oved, 1979).

${ }^{6}$ Gveret Keresh U'Mar Maarokh (Ben Shemen: Modan, 1982).

${ }^{7}$ Haruzim Te'imimim (Ben Shemen: Modan, 2007).

${ }^{8}$ Savta Minna Mibinyamina (Ben Shemen: Modan, 2009).

${ }^{9}$ Lyrics appear on the National Library of Israel, The House of Hebrew Songs website <http://zemer.nli.org.il/song/Bait_Lazemer003951249> [accessed 21 January 2020].

${ }^{10}$ Ma'aseh B'ozenhaman (Holon: Zimzon, 1989).

${ }^{11}$ Lyrics appear on the Shironet website $<$ https://shironet.mako.co.il/artist?type=lyrics\&lang=1\&prfid=166\&wrkid=806> [accessed 21 January 2020].
} 


\section{Literature Review}

Many feminist studies have been conducted since the 1960s documenting how the mass media supports and perpetuates societal discrimination against women. Many studies, based on analysing different and varied texts, show how various cultural products present women and men as dichotomous opposites, and how the female image supports the traditional division of roles between the genders. 12 The term gender refers to differences between the sexes, which are not inborn but rather result from social acquisition, intended to label the dichotomous hierarchy between men and women - that men are physically stronger than women and are therefore superior.

Critical-feminist discourse analysis examines and criticizes the natural attitude towards roles required from a woman, her image as a beautiful and sexual object in the eyes of society, and the resulting effects on her self-esteem, identity, body image, life, and mental health.13 Gender-related attitudes influence defining women's role, status, place, image, and appearance. They build her identity and direct her behaviour.14 Hogan15 suggests examining how the portrayal of women affects their subjective reality. The visual portrayal of women in society is part of the social discourse, ruled by it, and internalized as accepted norms which create the reality acknowledged as self-understood. Texts create knowledge domains, understandings, and explanations, and portray phenomena which evolve into knowledge and eventually create the discourse of the domain. Visual portrayals of women are part of the discourse which constructs how gender is perceived - a perception which effects the balance of power in society. 16

Sexual stereotyping in children's literature

Children's books are one of the methods of transmitting culture to children and shaping their viewpoints.17 Books reflect the worldview of their authors, and the culture and society in which they were written. Children's literature is a significant socialization tool, transmitting ethical values which the writer wishes to pass on, in accordance with the society in which they were written and where the children - the addressees for the stories - grow up.18 Differences between the genders and attitudes toward the feminine and masculine domains are already recognizable during early childhood.

In Israeli Hebrew children's books published several decades ago, the masculine refers to traits associated with activity, competition, and achievement. The feminine domain referred to character traits associated with giving, ability to express feelings, and warmth.19 The first area referred to the world around, outside the individual. The second area referred to the interpersonal domain. In sexual stereotypical education, each sex is encouraged to develop only one side of its personality, and the second side is avoided or repressed, despite being no less important. Bem20 called the process that creates sex roles, sex typing. Meaning, the process in which it is expected that both boys and girls acquire and internalize a sexual identity and characteristics typical of their sex, in accordance with the culture and environment in which they live. According to Eichler,21 both sexes learn what behaviour is desirable and expected from their sex,

12 Dafna Lemish, 'Shavot Erekh Tikshorti: Mabat Feministi Al Hatikshoret Hayisra'elit,' in Tikshoret V'demokrati'ah Beyisra'el, ed. by Dan Caspi (Jerusalem: Hakibbutz Hame'uchad, 1997), pp. 119-141; Dafna Lemish, 'Nashim Yafot, Stereotipim Mekhu'arim: Dimuy Nashim Befirsum Hayisra'eli', in Nihul Hapirsum, 2 vols, ed. by Jacob Hornik, and Joshua Lieberman (Tel Aviv: Open University of Israel, 1994), I, pp. 116-120; Rachel Ostrowitz, Dimui Ha'ishah Batikshoret (Tel Aviv: Hamidrashah Lehashivah Socialistit, 1987).

${ }^{13}$ Marcia Germaine Hutchinson, 'Imagining Ourselves Whole: A Feminist Approach to Treating Body Image Disorders', in Feminist Perspectives on Eating Disorders, ed. by Patricia Fallon, Melanie A. Katzman and Susan C. Wooley (New York: The Guilford Press, 1994), pp. 152-170.

${ }^{14}$ Helene Burt, 'Women, Art Therapy and Feminist Theories of Development', in Feminist Approaches to Art Therapy, ed. by Susan Hogan (London and New York: Psychology Press, 1997), pp. 97-114; Susan Hogan, Feminist Approaches to Art Therapy); Deborah Lupton, 'Foreword', in Feminist Approaches to Art Therapy, ed. by Susan Hogan, pp. 1-9.

${ }^{15}$ Hogan, Feminist Approaches to Art Therapy; Susan Hogan, Gender Issues in Art Therapy (London and Philadelphia: Jessica Kingsley, 2003).

16 Michelle M. Lazar, Feminist Critical Discourse Analysis: Gender, Power and Ideology in Discourse (Basingstoke and New York: Palgrave Macmillan, 2005).

${ }^{17}$ Sagan and Katzowitz.

${ }^{18}$ P. Frankel and G. Leviani, 'Stereotipim Mini'im Began-Hayeladim - D'mui V'hitnahagut', at Eighth Scientific Conference of Ayalah (Educational, cultural, and academic bridging), (Tel Aviv, 1988).

${ }^{19}$ Avner Ziv, Dalia Zipstein, and M. Litan, 'Hevdelim Bein Haminim Bitfisat Stereotipim Gavri'im Venashi'im Etsel Mitbagrim Yisra'elim,' Hahinukh, 45, 1 (1972), 64-69.

${ }^{20}$ Sandra Lipsitz Bern, 'Gender Schema Theory: A Cognitive Account of Sex Typing', Psychological Review, 88, (1981), $354-364$.

${ }^{21}$ Margrit Eichler, The Double Standard: $\quad$ A Feminist Critique of Feminist Social Science (London: Croom Helm, 1980). 
and behave in accordance with these stereotypes. By constantly introducing the ideology which erects a separation between the public arena, which belongs to the boys, and the private one, which belongs to the girls, inequality and discrimination against women is maintained.22

If so, in the lives of young children the book serves as one of the primary socialization agents for learning sex roles, as well as the main cultural mechanism for structuring gender-oriented views regarding the significance of 'being a boy' or 'being a girl' in contemporary society, with these views presented superficially.23 Using uniform and unchanging images and models for emulation, these perspectives are the source for learning values, behaviour, and expectations from themselves and others. From these perspectives, children learn what is accepted and usual for members of their sex - including the range of professions they are suited for, expectations regarding couples relationships, marriage and family - and thus the range of possibilities open to them as scenarios for their life as adults.

The way men and women or boys and girls are reflected in children's books has impact and children - from early childhood - understand the desired model: boys understand that masculine characteristics, that are strong and full of empowerment, are respected in society and they aspire to adopt a masculine model, and the girl understands she is better off adopting the feminine soft, motherly, and maternal model, which the masculine world views as weaker.24 The change in the image of the woman-mother in Israeli Hebrew children's literature, particularly in folktales and stories, is carried out by splitting her into two entities - good and bad - it is reflected in the dichotomies between the figures, characterized by stereotypes and representing human characteristics rather than literary images.25 Structuring the Other is a complex, deep, and long process.26 To slowly introduce an idea, perspective, or ruling paradigm, it needs to be structured methodically on the way we think. Education, literature, art, advertising, song, myths and legends - all these and more deeply influence how we all think.27 In the Hebrew story of Creation, the evil woman, Lilith, is already defined. Lilith who was created together with Adam, who refused to listen to them, and therefore left the Garden of Eden and turned into a witch who frightens children.28 She portrays the active, temptress, sexual, woman, who drags men to sin. She is the character of the biblical witch. Thus, even folktales have the good mother versus the evil stepmother, the wise grandmother versus the old witch.29 Splitting good and bad is a repeated element in Israeli Hebrew children's folktales, and they allow a simple worldview, particularly for children, 'This experiential split is also projected by the young child onto the world, which is understood in a split and conflicting manner: good and bad, masculine and feminine, pain and pleasure, black and white, and more'.30

Emergence of the grotesque woman in Israeli children's literature

The tendency toward sexism in the ridiculous descriptions of women features more during the 1980s than in the Israeli Hebrew children's books of the 1950s. During the 1950s, the adults were described from a perspective of honour and appreciation. In contrast, in the Israeli Hebrew literature of the 1980s, respect for adults has almost completely vanished, and most of what the mother or woman does is ridiculed.

According to Israeli norms common until the 1970s, the mother figure, like the father figure, was authoritative and taught behavioural norms. This figure was presented using correct and normative language, with an educational overtone, both when parents issued direct requests to their children or reacted to their child's behaviour, and also regarding indirect comments and the hidden messages.31 From the 1970s onwards, Israeli Hebrew children's literature

\footnotetext{
${ }^{22}$ Dafna Lemish, 'Hapolitikah Shel Hadrat Mi'ut Batikshoret: Dimuy Nashim Vesikur Ha'alimut Negdan', in Tikshoret U'politikah Beyisra'el, ed. by Dan Caspi (Jerusalem: Van Leer Institute and Hakibbutz Hame'uchad, 2008), pp. 185-207.

${ }^{23}$ Dafna Lemish, Children and Television: A Global Perspective (Oxford: Blackwell, 2007).

${ }^{24}$ Dorit Sharon, 'Steriotipim Miniyim V’tafkidey Min Besifray Yeladim Bagil Harakh', Al Mah: Ktav Et Lekidum Ma'amad Ha'ishah, 7 (2000), <http://lib.cet.ac.il/pages/item.asp?item=9680> [accessed 8 January 2020]; Chandrika Devarakonda, Diversity and Inclusion in Early Childhood: An Introduction (London: Sage, 2013).

${ }^{25}$ Abraham Zifroni, 'Hashva'at Hastereotip Hagavri L'stereotip Hanashi Legabay Tekhunot V'tafkidim B'kerev Talmidey Tikhon' (unpublished master's thesis, Tel Aviv University, 1981).

26 Tali Shaul, 'Ma Bein Sinderela L'ekofeminizim?' (unpublished master's thesis, Lesley University, 2009)

$<\mathrm{http}: / /$ www.talishaul.co.il/about1-c1j8d $>$ [accessed 8 January 2020].

27 Bruno Bettelheim, The Uses of Enchantment: The Meaning and Importance of Fairy Tales (New York: Knopf, 1976).

${ }^{28}$ Diane Stein, The Women's Spirituality Book (Woodbury, MN: Llewellyn, 1986).

${ }^{29}$ Riva Peri, Ma'aseh Biyetsirah: Tahalikh Hayetsirah, Mitusim V'agadot (Ben Shemen: Modan, 2005).

${ }^{30}$ Avi Baumann, Se'arot Hazahav Shel Hashad. Agadot Grim Kire'i Letzad Ha'afel Shel Hanefesh (Ben Shemen: Modan, 2005), p.41

${ }^{31}$ Zofia Meller, Hishtakfut Stereotipim Minaniyim Besifre Limud Bahinukh Hamamlakhti Beyisra'el (1991)

http://lib.cet.ac.il/pages/item.asp?item=3089 [accessed 21 December 2019].
} 
is no longer seen as a tool for imparting educational values. It is therapy-oriented literature. Therefore, even if the mother is as an authoritative figure in some of the stories (in others she lost her power as an educator a long time ago), she often appears as a totally countereducational figure. Even though human, including Israeli, society is currently undergoing rapid processes of gender equality, studies examining the images of gender in Israeli media consistently point at a world picture which still perpetuates the marginality of women in society and testifies that the changes are too slow and unacceptably inadequate. 32

The panoramic picture emerging from Israeli Hebrew children's books is of stereotyping, imparting each gender with clear personality traits and characteristics while barely referring to each individual's uniqueness. 33 The reason lies in the socialization processes the children themselves undergo, and in the messages from the adult world emphasizing to the children the difference between men and women and thus leading them to form their gender identity.34 It is the nature of things that children's literature, reflecting the children's immediate world, contains these messages: 'the values there [in the stories] expressed penetrate into the deepest recesses of the mind, where, even in our time, they are guarded as hallowed and immutable truths'.35 It is important to remember that women, like men, have no inborn characteristics in the cognitive, emotional-behavioural, or value-ethical fields. 36

In recent years, Israeli Hebrew children's literature has been working hard to develop the feminist model, with the central theme of arousing awareness of gender equality. However, the classic Hebrew children's stories, published several decades ago and captive to gender-oriented concepts, still occupy the home and preschool bookshelves, with children still exposed to erroneous gender philosophies. This article will discuss one of the many gender-oriented perspectives: how the image of women is painted in Israeli Hebrew children's literature as a seemingly gender-oriented stereotype, and from a contemporary viewpoint, it will suggest viewing her image as representative of a covert and overt feminist protest.

\section{Article goal}

The article's goal is to examine the stereotypical characteristics of female images in Israeli Hebrew children's stories and whether the way the figure of the woman was painted can be interpreted in the children's books discussed here, as a social and feminist protest.

Findings and discussion

Hannah Zeldah, Grandmother Bilhah, and Grandmother Minna from Binyamina - Are they really absentminded and forgetful?

In the song by Talma Alyagon Roz and Haya Frankel, Ma'aseh B'levivot, Hannah Zeldah is portrayed as a stereotypical image of a housewife charged with cooking and baking, who repeatedly sends her husband to buy yet another missing ingredient for preparing Hanukah potato pancakes, because Rabbi Kalman, her husband 'so desires a warm and sweet pancake'. Reading between the lines, we notice that Hannah Zeldah does not send Rabbi Kalman with an organized shopping list, but bothers him repeatedly, separately for each item. Thus she turns Rabbi Kalman himself, who unquestioningly obeys her, into a pathetic figure who arouses pity mixed with humour.

Likewise, Grandmother Bilhah from Levin Kipnis's story Ma'aseh B'ozenhaman fits the stereotypical image of an old woman - confused, absentminded, who constantly remembers another item she requires to bake oznei haman [triangular Purim holiday cakes], which her husband, Grandfather Habakuk, very much desires. Insidiousness is expressed here too, in the stereotype of bothering her husband.

In both texts, the husband desires a certain food. He is waiting for the warm potato pancake or the sweet ozen haman pastry, but in both cases, his absentminded wife (or perhaps she is deliberately scatter-brained so as to postpone preparing the food, and not make such efforts just because her husband is so desirous of a particular food) puts off the task. In both texts the addressee feels disorder and embarrassment regarding the poor management - a situation in which the woman (and her husband) are described as grotesque figures who again make the same mistake as in the previous verse or paragraph, not checking exactly what was missing to prepare the desired recipe, and became victims of this mockery - one behaves tyrannically, and the other continues going out as ordered to do, without checking.

\footnotetext{
${ }^{32}$ Lemish, 'Hapolitikah Shel Hadrat Mi’ut Batikshoret: Dimuy Nashim Vesikur Ha'alimut Negdan'.

${ }^{33}$ Sharon.

${ }^{34}$ Sandra Smidt, The Developing Child in the 21st Century: A Global Perspective on Child Development, 2nd edn (New York: Routledge, 2013), p. 108.

${ }^{35}$ Riane Tennenhaus Eisler, The Chalice and the Blade (NY: HarperCollins, 1987), p. 84.

${ }^{36}$ Gizi Rappaport, 'Ma Notar Min Hati'un Sheyeshnam Hevdelim Muladim Ben Haminim', in Matsa Min Et Shivyono Mikra'ah L'ovdey Hahora'ah, ed. by Naava Sagan, pp. 17-23.
} 
Grandmother Bilhah and Hannah Zeldah do not suffer from forgetfulness or absentmindedness, as could be gleaned from first impressions of the song and story. Do they deliberately repeatedly send their husband with various requests regarding a lack of a particular ingredient to prepare the pancakes or oznei haman? It would seem they are trying to tire their husband - who wanted the food - and lead him to despair, to create some time for themselves, while they delay their entry into the kitchen. Hannah Zeldah goes even further, and declares after each of her husband's errands that she is exhausted, and hints to him that he should kindly make the pancakes himself. Although Grandmother Bilhah does indeed knead the dough at the end of the story, Grandfather also has a role - lighting the stove. Whether deliberately or not, Grandmother Bilhah doubles and even triples the quantities of the dough ingredients, and thus, by morning, the ozen haman has risen so much that it cannot be removed from the stove - a kind of exaggerated fulfilling of the request, which includes a feminist declaration containing a type of reproof and punishment.

Unlike Grandmother Bilhah and Hannah Zeldah, Datia Ben Dor's Savta Minna Mibinyamina is characterized by absentmindedness and forgetfulness not aimed at defying a husband his desire for food. Grandmother Minna wants to travel and visit her grandchildren, but every time she gets to the railway station, as well as on her way there, she gets delayed speaking to some person or another about her grandchildren. She lists them, takes out photographs, and... misses the train every time. Grandmother Minna is seemingly described as a grotesque female figure who does not successfully manage her time, and also repeats her mistake by missing the train again and again, every day. However, there is a kind of feminist climate in the story: an independent grandmother, who does not need a partner to help her, decides herself to travel, does not spend time at home, but rather goes out into the public arena and, in addition, humbly accepts that she missed the train and makes peace with her mistake, and decides to travel tomorrow. Her plans change with the circumstances - she does not complain she will not see her grandchildren today, but rather returns home to other pastimes which fill her life. While her grandchildren occupy the centre of her conversation, they are not the centre of her existence. Her existence revolves around her need to talk and have contact with people, even at the expense of meeting her grandchildren.

Hadoda Sheli Mirehov Hanevi'im, Gveret Achat Mirehov Bezalel, and Gveret Im Salim - Nameless women redefining themselves

'My aunt from Hanevi'im Street | Loved children more than anything else.' Thus begins Yoram Taharlev's story, Hadoda Sheli Mirehov Hanevi'im. The aunt, who is nameless - a stereotypical characterization for erasing women's identities - is revealed as a prolific mother, whose only desire in life is to have another child and yet another, because she simply... loves children. The repetitive element in the story reinforces the ridiculous situation, and after each additional child is born, the sentence is repeated: 'Because this aunt, from Hanevi'im Street, loved children more than anything else.' Here, too, the woman's role is at home, constantly repeating the same activity. Bringing more and more children into the world, filling her home with lots of children, portrays the image of the aunt as someone not bearing children for a correct, significant, and real reason, after consideration, but rather just as a toy for the previous, bored child.

But the illustrations, in their own language, express the exact opposite. The aunt appears extremely assertive - she stands with her feet astride, her finger in the air, a short, masculine hairstyle, and she tells the 'father' of the child (this is in the original, 'to his father' or 'then mother said to his father' and not 'to her husband') that she wants another child. In all the illustrations her husband always stands behind her, his hand hugging her shoulder.

The aunt's somewhat masculine figure contrasts with the movements of other female figures in Israeli Hebrew children's literature, whose movement is constrained, and who adopt a slow, measured walking pace and small steps, as compared to the masculine figures.37 The aunt from Hanevi'im Street doesn't constrict her space, but 'takes for herself' a central position in the illustration. The aunt demands the first four children from her husband. And it is only regarding the fifth child that the father actually asks the mother (aunt) to bring another child into the world, and she agrees and has twins. The aunt decides to have another brother, but a sister is born, the seventh child, who turns into a rebellious and boisterous feminine figure in her own right: 'This was a terribly wild girl $\mid$ And they called her the funny name of Devorah | And because she jumped and fell and broke things so much | She was missing one of her teeth.' It seems the daughter inherits her mother's character; she is not a stereotypical girl but one who behaves like a boy. The aunt is the one to issue clear instructions to the children to tidy up the mess they made. The aunt's husband is absent from the admonitions, the rebukes, and educating his children.

Perceptions of birth and motherhood

Every culture has a different attitude towards the experience of giving birth, and how it is perceived and the way it

${ }^{37}$ Gila Danino-Yona, Yeladot Tovot: Havnayat Yehasim Migdari 'im Besifrut Hayeladim Hayisra'elit Hakanonit (Tel Aviv: Resling, 2017). 
occurs teach a great deal about the society and its values.38 The birthing experience is an exclusive and inseparable part of women's experiences and identities in all societies and cultures worldwide. It changes their lives, bodily and emotional imagination, priorities, and even their perception of their identity, role, and place in society and the world.39 Despite being a universal occurrence, birth is a unique experience which effects every woman in a different emotional way.40 And despite their cultural differences, women throughout the world describe the birth of their child as the most significant event in their lives. 41

Motherhood and birth have always been loaded subjects in the feminist discourse.42 In the past, feminists rejected traditional forms of childbirth and motherhood, describing them as symbols of women's submission. 43 Nothing external forces the aunt from Hanevi'im Street to bring more and more children into the world. She does so only for her own personal reasons, and therefore although there is seemingly a description of a woman having many children and utilized only for this role, the story illustrates that this is her personal choice - to fulfil herself as a woman by having children. This is a woman's post-feminist protest - she wishes to define herself and her feminine identity specifically through her ability to give birth. She did not merit her own name throughout the story, but merited children with clear names, who redefine her.

Shopping as a female stereotype

The female figures in the works Gveret Achat Mirehov Bezalel by Yoram Taharlev and Gveret Im Salim by Haya Shenhav remained nameless, but with a great desire to shop, another seemingly stereotypical viewpoint, presenting women as having a weakness for shopping. But the two women being in the public sphere is in a manner that does not weaken or subjugate their image. They do not have any financial problems - they buy large quantities of things. However, the Lady from Bezalel Street wants almost every item she sees, and buys more and more goods, until at the end of the story everything falls down, scatters, and breaks, but the reader is not left to chuckle at her but rather at the situation.

The Lady with Baskets also boards a bus with lots of bags containing many purchases. The bags occupy all the seats and none are left for other people. But she exercises her authority and dominance over the other passengers and appropriates more and more seats for her baskets and shopping. Studies show human consumption possesses other, not necessarily rational, dimensions, creating complex consumer decision-making processes, frequently not even understood by the consumer himself.44 The consumer begins the buying experience with a certain level of cognitive expectations regarding what the product or service which he is buying can do. These expectations serve as a basis for judging the buying experience.45 The feminist protest of the Lady from Bezalel Street and of the Lady with Baskets is in realizing this buying experience, leaving the home expanse for the public one, their financial ability to buy and use more and more things, how the Lady from Bezalel Street spoils herself by buying herself a soft drink, and the assertiveness of the Lady with the Baskets who scolds a child and tells him to move and let her sit down after she has taken up all the other seats with her shopping bags.

\footnotetext{
${ }^{38}$ Janet Balaskas, New Active Birth: A Concise Guide to Natural Childbirth (London: HarperCollins, 1990); Omi Leisner, 'Hok Haleidah Kehok Medinat Yisra'el,' (unpublished doctoral thesis, Bar Ilan University, 2007); Jean Liedloff, The Continuum Concept: In Search of Happiness Lost (Cambridge, Massachusetts: Perseus Books, 1977).

${ }^{39}$ Jane M. Asher, Hapsikhologiah Shel Guf Ha'ishah (Kiryat Bialik: Ach, 1992); Diana Eidelman, Hakhanah Lehorut Al Hamifgash Im Haketanim Shehofkhim Otanu Ligedolim. (Jerusalem: Keter Publishing, 2005); Carol Gilligan, In a Different Voice: Psychological Theory and Women's Development (Harvard University Press: Cambridge, Massachusetts, and London, England, 1982).

${ }^{40}$ Anat Agmon-Langbord, 'Attachment Orientation and Maternal Representations among Women in the Transition to Motherhood,' Mifgash: Journal of Social-Educational Work, 21 (2005), 39-60; Yonah Rephael-Lev, Herayon Ha'olam Hapnimi (Tel Aviv: Zmora-Bitan, 1996); Daniel Stern and Nadia Bruschweiler-Stern, The Birth Of A Mother: How The Motherhood Experience Changes You Forever (New York: Basic Books, 1998), p. 57.

${ }^{41}$ Balaskas; Eidelman; Adrienne Rich, Of Woman Born: Motherhood as Experience and Institution (New York and London: W.W. Norton, 1995); Stern and Bruschweiler-Stern.

${ }^{42}$ Ariella Friedman, Ba'ah M'ahavah: Intimi’ut Vekoah Bizehut Hanashit (Jerusalem: Hakibbutz Hame’uchad, 1996); Gilligan; Rich.

${ }^{43}$ Bar-On; Gizi Rappaport, Al Hafeminizim U'mitnagdav (Tel Aviv: Dvir, 1993); Rephael-Lev; Tali Rosin, Mi Zeh Bikhlal Feminizem V'ekh Karah She'anahnu Lo Yodot Al Zeh Klum? (Tel Aviv: Zmora-Bitan, 2000).

${ }^{44}$ Leon G. Schiffman, Leslie Lazar Kanuk and Havard Hansen, Consumer Behaviour: A European Outlook (Harlow, UK: Prentice Hall, 2008).

${ }^{45}$ Chezy Ofir and Itamar Simonson, 'The Effect of Stating Expectations on Customer Satisfaction and Shopping Experience', Journal of Marketing Research, 44 (2007), 164-174.
} 
Gveret Keresh - A seductive female figure

Datia Ben Dor's Mrs. Cutting Board appears as a female stereotypical figure in the story - superficial and shallow - the very first thing she does after waking up in the morning is to apply makeup. She is also deaf to her surroundings - she has no idea that today pancakes are being made in the kitchen since her only desire is to leave the house, and all her requests to do so with a different friend are answered in the negative which lead to Mrs. Cutting Board's ridiculous response: 'I had a very sad day', as if all a person's feelings of joy or sadness depend on leaving the house. Every negative reply adds to the woman's pessimism: 'I'll have a very sad day'. Extreme emotions form the basis of humour in Israeli children's literature. Even her make-up which is taken from the food she bought: 'She painted her lips with red jelly, smeared pink pudding on her cheeks', make her image grotesque, as someone trying to beautify herself using materials which are not actual makeup products. The dissonance creates ludicrousness for the addressees. The hypersexuality in Mrs. Cutting Board's appearance as someone who applies makeup, further intensifies the centrality of the sexual appearance in the self-definition of femininity.46 Mrs. Cutting Board tries to entice a partner to join her using her exaggerated makeup.

Among girls, sexuality leads, among other things, to internalization of a worldview characterized by self-objectification, poor self-image, and an assumption that the body (as opposed to their personality, activity, and personal achievements) is the primary arena for their self-definition of femininity:

Visual language serves as a tool for expressing power and status in social interactions: the way in which patriarchal hegemony establishes a lack of gender equality in a visual manner, the way in which the visual images and expressions influence how the text is understood and interpreted.47

However, Mrs. Cutting Board, who, in the connotation of the material from which she is made is not particularly clever, and is also seductive, is revealed as far from stupid: she speaks in a high register and in rhyme. Even though she is unaware of what is happening in her home, she knows what is happening outside ('the morning is wonderful, my land is splendid') and asks to immerse in the Lake of Galilee. The use of the word immerse rather than 'wash herself' or 'splash', for example, is of cultural significance - ritual immersion spiritually purifies women and prepares cooking and eating utensils for use in Jewish law. And therefore, the immersion which Mrs. Cutting Board seeks out has a twin purpose - to purify herself as a female figure and make herself usable as a kitchen utensil. Additionally, she does not show her feelings, and to find a partner for the trip who will come willingly rather than out of pity, she internalizes: "II will have a very sad day," thought Mrs. Cutting Board.'

The sentence she thinks to herself is totally different in its tone and intonation from that said to all the kitchen utensils passing her by: 'Do you want to go on a trip? The morning is wonderful, my land is splendid...' She repeatedly relates the description of the wonderful morning and the splendid land, in total contrast to the sad sentence in her heart, which comes immediately after each utensil's refusal to accompany her.

Mrs. Cutting Board is excluded twice over: once professionally (she is not needed as a kitchen utensil for preparing pancakes) and again socially (the utensils she meets are in a hurry and do not have time for her). But this exclusion only strengthens her, if we pay attention to the word I in the sentence when she approaches others: 'I so want to immerse in the Lake of Galilee'. The reason Mrs. Cutting Board is looking for one of the utensils to go with her on her trip is totally egocentric - the trip is for her. For her sake. To satisfy her desires.

Her feminist protest is expressed here in her wish to leave the kitchen at a time when all her friends are working hard. She does not stay, as would be expected according to the stigma of the merciful, empathetic, and inclusive female figure, to help them, but continues to find someone to leave with her. She eventually finds the best possible utensil for going on a shared trip, the utensil who knows how to respect her and is made from the same material as her: "My dear Mrs. Cutting Board, what do I have to do with preparing pancakes?" Mr. Rolling Pin said to her.' With one word, he restores her trampled honour, which she experienced with the many previous rejections, and therefore she chooses him as her partner on the trip. She does not need him to direct her, since they leave the kitchen as equals, and not one after the other: 'They linked arms and left.' Ben Dor ends the story using the omniscient narrator technique: We wonder what will happen in the evening when they return tired but happy. Will they find pancakes or crumbs on their plates? It seems the question does not bother Mrs. Cutting Board in the least. She prefers to remain hungry or just eat crumbs, so long as she can get out of a day working in the kitchen and enjoy the freedom outside.

\footnotetext{
${ }^{46}$ M. Gigi Durham, The Lolita Effect: The Media Sexualization of Young Girls and What We Can Do About It (Woodstock and New York: Overlook Press, 2008); Diane E. Levin and Jean Kilbourne, So Sexy So Soon: The New Sexualized Childhood and What Parents Can Do to Protect Their Kids (New York: Ballantine Books, 2008).
}

47 Duane A. Hargreaves and Marika Tiggemann, 'Idealized Media Images and Adolescent Body Image: "Comparing" Boys and Girls', Body Image, 1 (2004), 351-361 as defined by Danino-Yona, p. 15. 
Mrs. Shula - Sarcasm about compulsive eating

Datia Ben Dor's book Haruzim Te'imimim describes boys and girls eating different foods, with the name of each boy or girl rhyming with the name of the food. But at the end of the story, Mrs. Shula also appears: 'And what does Mrs. Shula eat? What you give her!' The illustration shows a fat woman eating everything in sight: fruit, vegetables, and cakes. The book was written in 2007, a time when the feminine beauty ideal was thinness. Recently, another ideal has begun to replace it or enter alongside the old ideal. In the new feminine beauty ideal, overweight women are also considered beautiful, successful, and self-confident in their body image and abilities.

The book, Nashim Okhlot Et Atsman: Al Anoreksiah, Bulimiah, V'eakhilah Kefiyatit48 [Women eating themselves: About anorexia, bulimia, and compulsive eating] emphasizes that many women and girls in Israel and worldwide, who are successful and show initiative and willpower in every other area of their lives, feel a total loss of control in regard to food. They live a double life. Outwardly people see a woman who functions in all areas. She is often good-looking, well-groomed, sometimes has a successful business, but in secret her life revolves around food, she has obsessive thoughts about eating, secret vomiting, binging when no one sees, self-starvation sometimes to the point of death, all accompanied by deep pain and suffering. What is common to all these women is the great frustration and anger they carry for years, and their inability to fulfil their emotional needs. Food is compensation, that sometimes becomes utterly destructive. In his book, Kim Chernin49 also emphasizes that hunger, expressed through food, covers our deep need for realizing a developed and autonomous identity that can satisfy our authentic hunger. Eating disorders are emotional and psychological disorders linked to poor eating habits, distorted body image, and compulsive occupation with body weight.50 Many women develop abnormal and unhealthy eating habits so as to meet the social thin ideal.51 A possible explanation for gender-based differences is that a high bar has been set for women in Western society in many areas professionally, socially, and personally, including functioning as a mother and wife. 52 The social pressure to be perfect in all these areas and fulfil all the roles, can lead to symptoms of eating disorders.53 Therefore, women report that controlling their bodies leads them to a type of control over the social world.54

Mrs. Shula rebels against all the definitions of eating disorders and control over the body. She has hidden feminist criticism regarding thinness and beauty and eats without caring about what others say or how they judge her body size. Ben Dor's Mrs. Shula brings the good news to all the overweight women: to be themselves and love their bodies. The illustrations show Mrs. Shula looking very happy at the sight of all the calorie-laden foods put out before her.

\section{Summary}

This article suggests a new way of reading familiar Israeli Hebrew children's books in which the image of the grotesque woman, who appears to be characterized in the literary texts discussed here with stereotypical definitions: she is required to prepare special festival foods, has a passion for shopping, is seductive, has many children, is forgetful and gluttonous.

When rereading we discovered that beneath the gender-oriented cloak, each of the women in these texts wanted to go on her own rite of passage journey, to shatter conventions, to be active while becoming the real heroine of the story or song, and overcoming being overemotional (crying, gentleness, pampering), characteristics of most of the children's books starring girls.

Reading between the lines, we learn that shopping testifies to financial independence, having many children and being fat indicate doing what a person wishes and not what society wishes or expects, entering the kitchen is not a given, and not going in is pushed off with various excuses. It would seem that each of the grotesque women in the stories and songs did not have complete freedom to choose and create as a whole, authentic, aware, and transcendent person, and

\footnotetext{
${ }^{48}$ Mira Dana, and Marilyn Lawrence, Nashim Okhlot Et Atsman: Al Anoreksiah, Bulimiah, V'eakhilah Kefiyatit (Ben Shemen: Modan, 2005).

${ }^{49}$ The Hungry Self: Women, Eating and Identity (New York: Times Books, 1985).

${ }^{50}$ Lee Keung George Hsu, Eating Disorders (New York: Guilford, 1990).

${ }^{51}$ Meyran Boniel-Nissim, and Azy Barak, 'Pro-Ana: Teenage Girls Hidden in Cyberspace', Mifgash: Journal of Social-Educational Work, 29 (2009), 171-91 (p. 174).

52 Ibid.

${ }^{53}$ Richard A. Gordon, Eating Disorders: Anatomy of a Social Epidemic, 2nd edn (Oxford: Blackwell, 2000); Janell Lynn Mensinger, Deanne Zotter Bonifazi and Judith LaRosa, 'Perceived Gender Role Prescriptions in Schools, the Superwoman Ideal, and Disordered Eating Among Adolescent Girls', Sex Roles, 57 (2007), 557-568.

${ }^{54}$ Robyn Goodman, 'Flabless is Fabulous: How Latina and Anglo women Read and Incorporate the Excessively Thin Body Ideal into Everyday Experience', Journalism and Mass Communication Quarterly, 79 (2002), 712-727.
} 
each one's protest was on the personal, feminine, and public plane.

Perhaps the choice of a grotesque, humorous image of a mother and woman came after the initial crisis of the first years after the establishment of the State of Israel, during which most women and mothers had experienced the Shoah or emigration, and were serious, gloomy, and anxious mothers devoted to educating their children and incredible housewives. Possibly the authors who wrote about the grotesque mother figure tried to inject her with a little bit of a spirit of mischief, freedom from responsibility and the residues of the past, and to mould her as a figure free of having to raise children and being obsessed with their wishes, aspirations, and dreams. The authors tried to tell us in these stories, that here is a woman and mother with her own wishes - the Lady from Bezalel Street buys whatever she wants; Grandmother Minna from Binyamina travels, or does not travel, to visit her grandchildren on the train; Mrs. Cutting Board wants to go on a trip, and for the aunt from Hanevi'im Street everything happens exactly in contrast to that usual of the stereotypical mother's role. This is a covert protest against bourgeoisie, order, and permanence. The female image in these stories is relatively unlike the norm, and is accompanied by a breath of fresh air of humour, endless freedom, but also humanity, love, and compassion.

Obvious sexism can be seen in the Hebrew Israeli children's literature about 'the ridiculous woman', meaning ascribing a secondary status to women in society while deliberately ignoring women's activity and achievements. In the texts discussed in this article, women are represented in activities and roles without social prestige - they raise children, travel to their grandchildren, or go on shopping sprees. Moreover, most of the women are presented as having negative character traits: being stupid, confused and bewildered, dysfunctional, frightened, hopeless, behaving in an exaggerated fashion, and helpless.

The gender aspect in Hebrew Israeli children's literature for young children lies at the centre of the postmodern discourse. The need to re-examine classic literary works from the last century, while passing a critical eye over the various images of women in these works is a current necessity. These are the literary works which shaped people's perspectives, from early childhood. The article suggests a critical view of these works, while examining and airing once again the world of concepts and the various images.

The article does not intend to question the literary value of each of the classic works discussed here, but rather to sharpen and attract the attention of educators, teachers, and preschool teachers to the array of gender-based images within them, and allow them to identify hidden insidious attitudes in the texts, even when unintentional. Children's literature, together with additional agents of socialization, helps children form their individual and social identity. 55 Discussion and conversation with children regarding the essence of the gender-oriented viewpoint in shaping the grotesque woman, its motives and other insights that can be reached through the figure's activity, conversation, and behaviour, can serve as a tool for the development of a person capable of critical thinking, independence, and values.

\section{References}

- (2009). Savta Minna Mibinyamina (Ben Shemen: Modan) (1979). Hadoda Sheli Mirehov Hanevi'im (Tel Aviv: Am Oved)

(1993b). 'Ma Notar Min Hati'un Sheyeshnam Hevdelim Muladim Ben Haminim', in Matsa Min Et Shivyono Mikra'ah L'ovdey Hahora'ah, ed. by Naava Sagan (Jerusalem: Ministry of Education), pp. 17-23

(1997). 'Shavot Erekh Tikshorti: Mabat Feministi Al Hatikshoret Hayisra'elit,' in Tikshoret V'demokrati'ah Beyisra'el, ed. by Dan Caspi (Jerusalem: Hakibbutz Hame'uchad), pp. 119-141

(2003). Gender Issues in Art Therapy (London and Philadelphia: Jessica Kingsley)

(2007). Children and Television: A Global Perspective (Oxford: Blackwell)

(2007). Haruzim Te'imimim (Ben Shemen: Modan)

(2008). 'Hapolitikah Shel Hadrat Mi'ut Batikshoret: Dimuy Nashim Vesikur Ha'alimut Negdan', in Tikshoret U'politikah Beyisra'el, ed. by Dan Caspi (Jerusalem: Van Leer Institute and Hakibbutz Hame'uchad), pp. 185-207

Agmon-Langbord, A. (2005). 'Attachment Orientation and Maternal Representations among Women in the Transition to Motherhood,' Mifgash: Journal of Social-Educational Work, 21, 39-60.

Alyagon, R., \& Ma'aseh B'levivot, T. (2020). National Library of Israel, The House of Hebrew Songs website $<$ http://zemer.nli.org.il/song/Bait_Lazemer003951249> [accessed 21 January 2020]

${ }^{55}$ Frankel and Leviani. 
Asher, J. M. (1992). Hapsikhologiah Shel Guf Ha'ishah (Kiryat Bialik: Ach)

Balaskas, J. (1990). New Active Birth: A Concise Guide to Natural Childbirth (London: HarperCollins)

Bar-On, Y. (2000). Ro'ot Et Hanolad. Leidah Veyilud Likrat Ha'idan Hamoderni (Tel Aviv: Haifa University and Zmora-Bitan Publishing House)

Baumann, A. (2005). Se'arot Hazahav Shel Hashad. Agadot Grim Kire'i Letzad Ha'afel Shel Hanefesh (Ben Shemen: Modan)

Ben Dor, D. (1982). Gveret Keresh U'Mar Maarokh (Ben Shemen: Modan)

Bern, S. L. (1981). Gender Schema Theory: A Cognitive Account of Sex Typing. Psychological Review, 88, 354-364

Bettelheim, B. (1976). The Uses of Enchantment: The Meaning and Importance of Fairy Tales (New York: Knopf)

Boniel-Nissim, Meyran, and Azy Barak. (2009). Pro-Ana: Teenage Girls Hidden in Cyberspace. Journal of Social-Educational Work, 29, 171-91.

Burt, H. (1997). Women, Art Therapy and Feminist Theories of Development, in Feminist Approaches to Art Therapy, ed. by Susan Hogan (London and New York: Routledge), pp. 97-114

Chernin, K. (1985). The Hungry Self: Women, Eating and Identity (New York: Times Books)

Dana, M., \& Marilyn, L. (2005). Nashim Okhlot Et Atsman: Al Anoreksiah, Bulimiah, V'eakhilah Kefiyatit (Ben Shemen: Modan)

Danino-Yona, G. (2017). Yeladot Tovot: Havnayat Yehasim Migdari'im Besifrut Hayeladim Hayisra'elit Hakanonit (Tel Aviv: Resling)

Desheh, M. (1969). Hinukh Likri'ah Tovah: Al Sifrut Yeladim V'al Ba'ayot Hakri'ah Hahofshit (Tel Aviv: Am Oved)

Devarakonda, C. (2013). Diversity and Inclusion in Early Childhood: An Introduction (London: Sage)

Durham, M. G. (2008). The Lolita Effect: The Media Sexualization of Young Girls and What We Can Do About It (Woodstock and New York: Overlook Press)

Eichler, M. (1980). The Double Standard: A Feminist Critique of Feminist Social Science (London: Croom Helm)

Eidelman, D. (2005). Hakhanah Lehorut - Al Hamifgash Im Haketanim Shehofkhim Otanu Ligedolim. (Jerusalem: Keter Publishing)

Eisler, R. T. (1987). The Chalice and the Blade (NY: HarperCollins).

Frankel, P., \& Leviani, G. (1988). 'Stereotipim Mini'im Began-Hayeladim - D'mui V'hitnahagut', at Eighth Scientific Conference of Ayalah (Educational, cultural, and academic bridging), Tel Aviv

Friedman, A. (1996). Ba'ah M'ahavah: Intimi’ut Vekoah Bizehut Hanashit (Jerusalem: Hakibbutz Hame'uchad)

Germaine, H. M. (1994). 'Imagining Ourselves Whole: A Feminist Approach to Treating Body Image Disorders', in Feminist Perspectives on Eating Disorders, ed. by Patricia Fallon, Melanie A. Katzman and Susan C. Wooley (New York: The Guilford Press), pp. 152-170

Gilligan, C. (1982). In a Different Voice: Psychological Theory and Women's Development (Harvard University Press: Cambridge, Massachusetts, and London, England).

Goodman, R. (2002). 'Flabless is Fabulous: How Latina and Anglo women Read and Incorporate the Excessively Thin Body Ideal into Everyday Experience', Journalism and Mass Communication Quarterly, 79: 712-727

Gordon, R. A. (2000). Eating Disorders: Anatomy of a Social Epidemic, 2nd ed. (Oxford: Blackwell)

Hargreaves, D. A., \& Marika, T. (2004). Idealized Media Images and Adolescent Body Image: "Comparing" Boys and Girls. Body Image, 1, 351-361.

Hogan, S. (1997). Feminist Approaches to Art Therapy (London and New-York: Psychology Press)

Hsu, L. K. G. (1990). Eating Disorders (New York: Guilford)

Kipnis, L. (1989). Ma'aseh B'ozenhaman (Holon: Zimzon)

Krasney, A. (2005). Hatefisah Hastereotipit Shel Demut Ha'ishah Besifrut Hayeladim. Sha'anan, 10, 197-216.

Leisner, O. (2007). 'Hok Haleidah Kehok Medinat Yisra'el,' (unpublished doctoral thesis, Bar Ilan University)

Lemish, D. (1994). 'Nashim Yafot, Stereotipim Mekhu'arim: Dimuy Nashim Befirsum Hayisra'eli', in Nihul Hapirsum, 2 vols, ed. by Jacob Hornik, and Joshua Lieberman (Tel Aviv: Open University of Israel), I, pp. 116-120. 
Levin, D. E., \& Jean, K. (2008). So Sexy So Soon: The New Sexualized Childhood and What Parents Can Do to Protect Their Kids (New York: Ballantine Books)

Liedloff, J. (1977). The Continuum Concept: In Search of Happiness Lost (Cambridge, Massachusetts: Perseus Books)

Lupton, D. (1997). 'Foreword', in Feminist Approaches to Art Therapy, ed. by Susan Hogan (London and New York: Psychology Press), pp. 1-9

Meller, Z. (1991). Hishtakfut Stereotipim Minaniyim Besifre Limud Bahinukh Hamamlakhti Beyisra'el. http://lib.cet.ac.il/pages/item.asp?item=3089 [accessed 21 December 2019]

Mensinger, J. L., Deanne, Z. B., \& Judith, L. R. (2007). Perceived Gender Role Prescriptions in Schools, the Superwoman Ideal, and Disordered Eating Among Adolescent Girls. Sex Roles, 57, 557-568.

Ofir, C., \& Itamar, S. (2007). The Effect of Stating Expectations on Customer Satisfaction and Shopping Experience. Journal of Marketing Research, 44, 164-174.

Ostrowitz, R. (1987). Dimui Ha'ishah Batikshoret (Tel Aviv: Hamidrashah Lehashivah Socialistit)

Peri, R. (2005). Ma'aseh Biyetsirah: Tahalikh Hayetsirah, Mitusim V'agadot (Ben Shemen: Modan)

Rappaport, G. (1993a). Al Hafeminizim U’mitnagdav (Tel Aviv: Dvir)

Rephael-Lev, Y. (1996). Herayon Ha'olam Hapnimi (Tel Aviv: Zmora-Bitan)

Rich, Adrienne. (1995). Of Woman Born: Motherhood as Experience and Institution (New York and London: W.W. Norton)

Rosin, T. (2000). Mi Zeh Bikhlal Feminizem V'ekh Karah She'anahnu Lo Yodot Al Zeh Klum? (Tel Aviv: Zmora-Bitan)

Sagan, N., \& Katzowitz, A. (1995). 'Stereotipim Gavri'im U'nashi'im Besifre Limud Uvesifrut Yeladim V'no'ar' in Matsa Min Et Shivyono, ed. by Nava Sagan (Jerusalem: Israeli Ministry of Education)

Schiffman, L. G., Leslie, L. K., \& Havard, H. (2008). Consumer Behaviour: A European Outlook (Harlow, UK: Prentice Hall)

Sharon, D. (2000). 'Steriotipim Miniyim V'tafkidey Min Besifray Yeladim Bagil Harakh', Al Mah: Ktav Et Lekidum Ma'amad Ha'ishah, 7, <http://lib.cet.ac.il/pages/item.asp?item=9680> [accessed 8 January 2020]

Shaul, T. (2009). 'Ma Bein Sinderela L'ekofeminizim?' (unpublished master's thesis, Lesley University) $<$ http://www.talishaul.co.il/about1-c1j8d $>$ [accessed 8 January 2020]

Shenhav, Haya. Gveret Im Salim, Shironet website $<$ https://shironet.mako.co.il/artist?type=lyrics\&lang=1\&prfid=166\&wrkid=806 $>$ [accessed 21 January 2020]

Smidt, Sandra. (2013). The Developing Child in the 21st Century: A Global Perspective on Child Development, 2nd edn (New York: Routledge)

Stein, D. (1986). The Women's Spirituality Book (Woodbury, MN: Llewellyn)

Stern, D., \& Nadia, Bruschweiler-Stern. (1998). The Birth of a Mother: How the Motherhood Experience Changes You Forever (New York: Basic Books)

Taharlev, Y. (1968). Gveret Achat Mirehov Bezalel (Ben Shemen: Modan)

Zifroni, A. (1981). 'Hashva'at Hastereotip Hagavri L'stereotip Hanashi Legabay Tekhunot V'tafkidim B'kerev Talmidey Tikhon' (unpublished master's thesis, Tel Aviv University)

Ziv, A., Dalia, Z., \& Litan, M. (1972). Hevdelim Bein Haminim Bitfisat Stereotipim Gavri'im Venashi'im Etsel Mitbagrim Yisra'elim. Hahinukh, 45(1), 64-69.

\section{Copyrights}

Copyright for this article is retained by the author(s), with first publication rights granted to the journal.

This is an open-access article distributed under the terms and conditions of the Creative Commons Attribution license which permits unrestricted use, distribution, and reproduction in any medium, provided the original work is properly cited. 